\title{
Genetic x environment interaction on agronomic characters and yield components of sweet sorghum (Sorghum bicolor) mutant strain
}

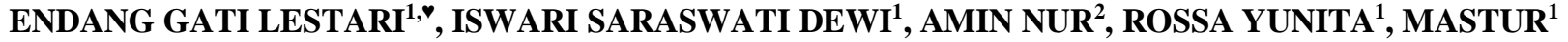 \\ ${ }^{1}$ Indonesian Center for Agricultural Biotechnology and Genetic Resources Research and Development. Jl. Tentara Pelajar No. 13, Bogor 16124, West \\ Java, Indonesia. Tel.: +62-251-8337975, ^email: endanggatilestari @gmail.com \\ ${ }^{2}$ Indonesian Cereals Research Institute. Jl. Dr. Ratulangi No.274, Maros 90512, South Sulawesi, Indonesia
}

Manuscript received: 19 September 2019. Revision accepted: 24 November 2019.

\begin{abstract}
Lestari EG, Dewi IS, Nur A, Yunita R, Mastur. 2019. Genetic x environment interaction on agronomic characters and yield components of sweet sorghum (Sorghum bicolor) mutant strain. Biodiversitas 20: 3705-3714. Sweet sorghum (Sorghum bicolor (L.) Moench) belongs to cereal plants that have prospects for commercial development in Indonesia, since it can adapt widely in sub-optimal land, and has many functions. However, there is still limited sweet sorghum variety that has been released in Indonesia. The study aimed to evaluate the influence of genetic $\mathrm{x}$ environment interaction on agronomic characters and yield components of sweet sorghum mutant strain. Adaptation test was held in 8 locations in Indonesia, namely Pekalongan, Bantul, Gunung Kidul, Lampung, Malang, East Lombok, Bontobili and Maros, from May to November 2017. The material tested was 10 M7 mutant strains and two check varieties (Numbu and Super 1). The experiment was arranged in a randomized complete block design (RCBD). There were three replications in form of blocks and each block consisted of 40 sorghum plants. The result showed that genetic x environment interaction affected the agronomic characters and yield components of sweet sorghum. Several characters such as plant height, panicle diameter, seed production, sugar brix and stem juice volume of sweet sorghum mutants were greater than check varieties. The highest seed yield was found in MB-1 strain of sweet sorghum mutant that cultivated in Pekalongan site.
\end{abstract}

Keywords: Genotype, Numbu, seed yield, Sorghum bicolor, sorghum breeding

\section{INTRODUCTION}

Sweet sorghum (Sorghum bicolor (L.) Moench) has been considered to be highly potential source of food and energy sustainability programs (Sungkono et al. 2009). Sweet sorghum has a high potential to be developed in Indonesia because it has an excellent adaptability in suboptimal land (Almodares and Hadi 2009; Regassa and Wortmann 2014). Sorghum is more tolerant than sugarcane and corn in terms of abiotic stress such as drought and acidity (Human 2010; Regassa and Wortmann 2014) and also more tolerant to saline soils (Almodares et al. 2007). The ratio of water requirements between sorghum and sugarcane is 1: $3.22 \%$ lower than corn (Kumar and Reddy 2014) .

Sorghum is a primarily self-pollinating plant, meaning that sorghum could accept pollen from its own flowers, while cross-pollination in sorghum is only less than $10 \%$ (Human and Sihono 2010). For breeding program, it is necessary to increase genetic diversity within the population as the selected material for breeding activities (Human and Sihono 2010; Oladosu et al. 2016). Plant breeding through mutations is needed to obtain new sorghum varieties with drought tolerance character so that it could be spread over in the suboptimal land with drought limiting factor (Human and Sihono 2010)

Plant breeding is a technology based on the art and science of changing the characteristics of plants to develop desired traits (Wanga et al. 2018, Roychowdhury and Tah 2011a; Roychowdhury and Tah 2011b). Sorghum breeders' interest in utilizing induced mutation aimed to create genetic variability in plant population to meet the need for yield, quality, resistance and environmental adaptation (Cheema and Khalsa 2018). Application of mutation techniques combined with in vitro culture for assembling new high yielding varieties has frequently reported (Pedriery 2001; Jain 2006). The advancement of in vitro techniques to accelerate the acquisition of new high yielding varieties using small-sized material such callus increased the opportunity of mutation occurred (Jain 2010).

According to Carvalho et al. (2002), the identification and selection of individual mutations, understanding the genetic control of the characters for the purpose of improvement, and confirmation of the desired character changes are important factors that determine the success of new varieties assembling through mutations. Mutation induction to obtain disease-resistant sorghum, droughttolerant and shorter stress has been previously reported by Human and Sihono (2010) and Wanga et al. (2018). Genetic variations in terms of morphological and physiological characters such as chlorophyll (albino, viridis, striata) mutations; leaves mutations (narrow, wide); morphological mutations (dwarfs, tall, twin rods), panicle mutations (twin panicles, compact, spread), and seed mutations (pink, brown, long, round, small) in the $2^{\text {nd }}$ generation of mutants have been obtained by irradiation at a dose 400 Gy in local sorghum (Htun et al. 2015).

Breeding program was held through gamma irradiation method combined with in vitro culture in sweet sorghum 
variety, namely Numbu. The mutant strains need to be tested for adaptation in order to obtain high and stable yielding strains so that it could be released as new varieties. The adaptation test aimed to evaluate the stability of genotype performance in particular environments, through analysis of genotype $\mathrm{x}$ environment interactions (Jain 2010; Rahayu et al. 2013). The adaptability and stability of genotype is strongly influenced by environmental conditions (Rahayu et al. 2013). The presence of multilocation test allows the breeder to select lines that have desired agronomic traits and yield components (Rayad and Idwar 2010). The success of plant varieties assembling is determined by the availability of genetic resources, extensive genetic variability, as well as the understanding of the genetic control of the improved characters (Yuliasti and Reflinur 2017). Analysis of genotype x environment interaction is one of important steps to estimate the suitability of mutant lines genotypes to adapt in various environmental conditions (Pabendon et al. 2012). The research aimed to evaluate the genetic $\mathrm{x}$ environment interaction on agronomic traits, yields, and components of sweet sorghum mutant strains.

\section{MATERIALS AND METHODS}

\section{Material}

Plant materials were 10 strains of sweet sorghum mutant obtained from the $7^{\text {th }}$ generation, as showed in Table 1. In addition, there were two check varieties, namely Numbu and Super 1. Numbu was also the elder of all obtained mutants so that as appropriate to use as a standard. Comparing Numbu to its mutant would display the improvement of desired characters. In contrast, Super 1 was not the elder of the tested mutants, however, this variety has already released as commercial sweet sorghum. Thus, the yield improvement of mutant was expected to higher than those two check varieties.

\section{Methods}

The multi-location test was conducted from May to November 2017, at eight study sites namely Pekalongan, Bantul, Gunung Kidul, Lampung, Malang, East Lombok, Bontobili and Maros. The experimental design was a Randomized Complete Block Design (RCBD) with single factor in form of 12 sweet sorghum genotypes. There were 3 replications arranged in 3 different blocks in all tested sites. For every block, there were 40 sorghum planted. The size of block was $3 \times 5 \mathrm{~m}$ (length $\mathrm{x}$ width), with a plant spacing of $75 \mathrm{~cm} \times 25 \mathrm{~cm}$.

To avoid initial pest attacks, seeds were treated using insecticide such Sevin and seeds were also sprinkled with carbofuran after planting. The first fertilizer was applied when plants aged 10-15 days after planting (DAP) with a dose of $150 \mathrm{~kg} \mathrm{ha}^{-1}$ of urea, $100 \mathrm{~kg} \mathrm{ha}^{-1}$ of SP36 and $75 \mathrm{~kg}$ $\mathrm{ha}^{-1}$ of $\mathrm{KCl}$. The second fertilizer was applied when plants aged 30-35 DAP with a dose of $150 \mathrm{~kg} / \mathrm{ha}$ of urea fertilizer. Other plant maintenance required such as watering and weeding were also done. Pest and disease control was carried out when plants were attacked by pests and diseases. Harvesting was done when the seeds begin to mature physiologically that was when the leaves turning to yellow and white with a clear black spot on the basal part. The observed variables were (i) plant height from base to the panicle exit $(\mathrm{cm})$, (ii) stem diameter $(\mathrm{mm})$, (iii) panicle length $(\mathrm{cm})$ from stem to tip panicle, (iv) seed weight per panicle, (v) sugar brix on the stem (\%), and juice volume $(\mathrm{ml})$. Those observations were performed on 10 individual plants for every sweet sorghum strain. Sugar brix was measured by using hand refractometer. The samples, for about 10 plants per strain, were prepared from the middle part of the sweet sorghum stalk. For the juice volume, there were also 10 stalks used as sample for each strain and determined by using cane press machine. The obtained data were analyzed using analysis of variance and combined analysis of variance. Any significant differences between treatments were further tested by Least Significance Different test at $\alpha=5 \%$.

\section{RESULTS AND DISCUSSION}

The combined analysis of variance was performed to measure the variance resulted from the genetic, environment and interaction of both factors on the agronomic characters and yield of sweet sorghum. The result in this study showed that there was significant effect caused by the genetic, environment and interaction of both factors, except the interaction of $\mathrm{G} \times \mathrm{E}$ on harvesting age (Table 2). According to Yuliasti (2016), showed that the potential yield of plant was affected either by genetics, environment or interaction of $\mathrm{G} \times \mathrm{E}$ on green bean mutant lines, information regarding genotype $\mathrm{x}$ environment interactions is needed in the selection of superior genotypes (Anasari et al 2017). The presence of interaction effect between genetic and environment indicated that each mutant strain had specific responses to certain environmental condition (Anasari et al. 2017). Rahayu et al. (2013) also reported that both adaptability and stability of plant genotype were strongly influenced by environmental conditions. Therefore, stability performance should be done by testing plant materials in multilocations. Rayad and Idwar (2010) have been conducted the stability test of several soybean genotypes in Riau Province, Indonesia.

Table 1. List of tested sweet sorghum mutants in the present experiment

\begin{tabular}{ll}
\hline Name & Note \\
\hline MB1 & All mutants were obtained from selection process \\
MB2 & in Bogor \\
MB3 & \\
MB4 & \\
MB5 & \\
MM1 & All mutants were obtained from selection process \\
MM2 & in Maros \\
MM3 & \\
MM4 & \\
MM5 & \\
\hline
\end{tabular}


The information on plant height, stem diameter, panicle length, and panicle diameter were very important to determine the direction of further development of sorghum whether for food ingredient, feed material or biofuel. In addition, there were also several important characters for the breeding and selection specific to the sweet sorghum varieties such as sugar Brix, plant biomass, and the stem juice volume (Pabendon et al. 2012)..

In general, sweet sorghum mutant strains showed greater agronomic characters and yield than two check varieties (Table 3). For the harvesting age and sugar Brix, some mutant strains showed higher results either than Numbu or Super1. For the character of panicle length, a few mutant strains did not show significantly higher results than two check varieties. The plant height of mutant strains was higher than Numbu as an elder, while the seed weight per panicle of all tested mutant strains was greater than Super 1 variety. In terms of flowering age, stem diameter, stem juice volume, and seed yield, all tested mutant strains showed better results than Numbu and Super 1. This finding showed the success of mutation to improve the plant performances. The mutation through gamma irradiation was previously reported to have random effect at cytoplasm, chromosome and even genome level (Jain 2010). Irradiation induced mutation produced a broader genetic diversity within mutant population. By having 7times selection process in previous time, all tested mutant in this experiment might show a great performance in its selection place, either Bogor or Maros. Thus, there was a need to test those performances in multiple locations.

Table 2. Mean squares of agronomic characters and yield components of sweet sorghum mutant and two check varieties cultivated in eight study sites during 2017

\begin{tabular}{|c|c|c|c|c|c|}
\hline Characters & $\mathbf{E}$ & $\mathbf{G}$ & G X E & Error & CV \\
\hline Flowering Age (DAP) & $186.63^{*}$ & $113.04 * *$ & $6.54 * *$ & 2.08 & 2.32 \\
\hline Harvest Age (DAP) & $928.91 *$ & $223.63 * *$ & $7.20 \mathrm{NS}$ & 5.40 & 2.35 \\
\hline Plant Height $(\mathrm{cm})$ & $25138.41^{*}$ & $6678.21 * *$ & $85.31 * *$ & 57.70 & 2.87 \\
\hline Stem Diameter $(\mathrm{cm})$ & $153.21 *$ & $30.94 * *$ & $8.34 * *$ & 0.77 & 6.19 \\
\hline Panicle Length $(\mathrm{cm})$ & $71.89 *$ & $75.28 * *$ & $9.24 * *$ & 1.88 & 6.69 \\
\hline Sugar Brix $(\%)$ & $91.20 *$ & $13.17 * *$ & $8.51^{* *}$ & 0.76 & 5.88 \\
\hline Juice Volume (ml) & $57275.29 *$ & $6094.60 * *$ & $1385.52 * *$ & 123.75 & 9.64 \\
\hline Seed Weight per Panicle (g) & $0.04 *$ & $0.002 * *$ & $0.004 * *$ & 0.0002 & 14.88 \\
\hline Yield (t/ha) & $20.39 *$ & $10.21 * *$ & $3.42 * *$ & 0.48 & 10.95 \\
\hline
\end{tabular}

Note: $* *=$ significantly different based on $\mathrm{F}$ test at $\alpha 1 \%$; $*$ significantly different based on $\mathrm{F}$ test at $\alpha 5 \%$; NS = not significantly different based on $\mathrm{F}$ test at $\alpha 5 \%$; $\mathrm{E}=$ environment, $\mathrm{G}=$ genetics, $\mathrm{G} \times \mathrm{E}=$ genetic $\mathrm{x}$ environment interaction, $\mathrm{CV}=$ coefficient of variation, DAP $=$ days after planting

Table 3. The mean value of agronomic characters and yield components of sweet sorghum mutant and two check varieties cultivated in eight study sites during 2017

\begin{tabular}{|c|c|c|c|c|c|c|c|c|c|}
\hline \multirow{2}{*}{ Strain } & FA & HA & PH & SD & $\mathbf{P L}$ & SB & JV & SPW & SY \\
\hline & DAP & & cm & $\mathbf{m m}$ & cm & $\%$ & ml & g & t.hat \\
\hline MB-1 & $63 a b$ & $101 a b$ & 259.0a & 14.02ab & 19.56 & $14.43 b$ & 118.49ab & $0.08 b$ & 6.41ab \\
\hline MB-2 & $64 a b$ & $101 \mathrm{ab}$ & $252.81 \mathrm{a}$ & 15.09ab & 19.59 & $15.36 \mathrm{ab}$ & $110.08 \mathrm{ab}$ & $0.08 b$ & $6.55 \mathrm{ab}$ \\
\hline MB-3 & $64 \mathrm{ab}$ & $99 b$ & $266.01 \mathrm{a}$ & $15.22 \mathrm{ab}$ & $21.37 \mathrm{a}$ & $15.15 \mathrm{ab}$ & $122.39 \mathrm{ab}$ & $0.08 \mathrm{~b}$ & $7.00 \mathrm{ab}$ \\
\hline MB-4 & $64 a b$ & $100 \mathrm{~b}$ & $267.77 \mathrm{a}$ & $14.66 \mathrm{ab}$ & $20.25 a$ & $14.89 \mathrm{ab}$ & $129.54 \mathrm{ab}$ & $0.07 \mathrm{~b}$ & $6.54 \mathrm{ab}$ \\
\hline MB-5 & $62 \mathrm{ab}$ & $101 \mathrm{ab}$ & $262.19 \mathrm{a}$ & $14.90 \mathrm{ab}$ & $21.19 \mathrm{a}$ & $14.60 \mathrm{~b}$ & $121.37 \mathrm{ab}$ & $0.08 \mathrm{~b}$ & 7.11ab \\
\hline MM-1 & $63 a b$ & $99 b$ & $262.62 \mathrm{a}$ & $13.78 \mathrm{ab}$ & $20.63 a$ & $15.10 \mathrm{ab}$ & $119.22 \mathrm{ab}$ & $0.08 \mathrm{~b}$ & $6.34 \mathrm{ab}$ \\
\hline MM-2 & $60 \mathrm{ab}$ & $99 \mathrm{~b}$ & $249.29 \mathrm{a}$ & $14.86 \mathrm{ab}$ & 18.86 & $15.89 \mathrm{ab}$ & $101.93 \mathrm{ab}$ & $0.08 \mathrm{~b}$ & $6.18 \mathrm{ab}$ \\
\hline MM-3 & $65 \mathrm{ab}$ & $98 \mathrm{~b}$ & $281.63 \mathrm{a}$ & $14.16 \mathrm{ab}$ & 19.62 & $16.24 \mathrm{ab}$ & $136.48 \mathrm{ab}$ & $0.08 \mathrm{~b}$ & $6.06 \mathrm{ab}$ \\
\hline MM-4 & $61 \mathrm{ab}$ & $99 b$ & $253.77 \mathrm{a}$ & $14.59 \mathrm{ab}$ & $20.69 a$ & $15.54 \mathrm{ab}$ & $113.92 \mathrm{ab}$ & $0.09 \mathrm{~b}$ & $6.98 \mathrm{ab}$ \\
\hline MM-5 & $64 \mathrm{ab}$ & $102 \mathrm{ab}$ & $282.61 \mathrm{a}$ & $14.53 \mathrm{ab}$ & 19.49 & $15.58 \mathrm{ab}$ & $133.79 \mathrm{ab}$ & $0.08 \mathrm{~b}$ & $6.47 \mathrm{ab}$ \\
\hline Numbu (a) & 59 & 99 & 235.95 & 12.31 & 19.06 & 14.31 & 84.49 & 0.08 & 5.55 \\
\hline Super 1 (b) & 59 & 90 & 298.43 & 12.51 & 25.49 & 13.59 & 92.27 & 0.06 & 4.78 \\
\hline Means & 62 & 99 & 264.60 & 14.22 & 20.48 & 15.06 & 115.33 & 0.08 & 6.36 \\
\hline SE & 1.44 & 2.33 & 7.60 & 0.87 & 1.37 & 0.89 & 11.12 & 0.01 & 5.82 \\
\hline Strain & $* *$ & $* *$ & $* *$ & $* *$ & $* *$ & $* *$ & $* *$ & $* *$ & $* *$ \\
\hline $\mathrm{CV}$ & 2.32 & 2.35 & 2.87 & 6.19 & 6.69 & 5.88 & 9.65 & 14.88 & 12.97 \\
\hline LSD 0.05 & 0.83 & 1.33 & 4.32 & 0.50 & 0.78 & 0.50 & 6.34 & 0.01 & 0.39 \\
\hline
\end{tabular}

Note: $\mathrm{a}=$ Significantly higher than Numbu variety based on LSD test at $\alpha 5 \%$; $=$ Significantly higher than Super 1 variety based on LSD test at $\alpha 5 \%$; Flowering Age (days), HA = Harvesting Age (days), $\mathrm{PH}=$ Plant Height $(\mathrm{cm}), \mathrm{SD}=\mathrm{Stem}$ Diameter $(\mathrm{mm}), \mathrm{PL}=$ Panicle Length $(\mathrm{cm}) ; \mathrm{PD}=$ Panicle Diameter $(\mathrm{mm}) ; \mathrm{SB}=$ Sugar Brix $(\%)$; JV = Stem Juice Volume (ml); SPW = Seed Weight per Panicle $(\mathrm{g}) ; \mathrm{SY}=$ Seed Yield $\left(\mathrm{t} \mathrm{ha}^{-1}\right) ; \mathrm{SE}=$ standard of error; $\mathrm{CV}=$ coefficient of variation, $\mathrm{DAP}=$ days after planting 
Table 4. Strain $x$ environment interaction on the flowering age (days) of sweet sorghum mutant and two check varieties cultivated in eight study sites during 2017

\begin{tabular}{lllllllll}
\hline Strain & BTB & MRS & MLG & LTM & PKL & LMP & GKL & BTL \\
\hline MB-1 & $64 \mathrm{ab}$ & $65 \mathrm{~d}$ & $62 \mathrm{abc}$ & $61 \mathrm{a}$ & $62 \mathrm{ab}$ & $63 \mathrm{bc}$ & $63 \mathrm{abc}$ & $63 \mathrm{abc}$ \\
MB-2 & $65 \mathrm{ab}$ & $71 \mathrm{ab}$ & $63 \mathrm{a}$ & $58 \mathrm{~b}$ & $62 \mathrm{ab}$ & $64 \mathrm{ab}$ & $64 \mathrm{a}$ & $64 \mathrm{ab}$ \\
MB-3 & $63 \mathrm{bc}$ & $71 \mathrm{ab}$ & $62 \mathrm{ab}$ & $61 \mathrm{a}$ & $62 \mathrm{ab}$ & $64 \mathrm{ab}$ & $63 \mathrm{abc}$ \\
MB-4 & $64 \mathrm{ab}$ & $70 \mathrm{ab}$ & $63 \mathrm{a}$ & $61 \mathrm{a}$ & $62 \mathrm{ab}$ & $65 \mathrm{ab}$ & $63 \mathrm{abc}$ & $64 \mathrm{ab}$ \\
MB-5 & $59 \mathrm{ef}$ & $69 \mathrm{bc}$ & $62 \mathrm{abc}$ & $60 \mathrm{ab}$ & $60 \mathrm{be}$ & $63 \mathrm{ab}$ & $61 \mathrm{cdef}$ \\
MM-1 & $58 \mathrm{ef}$ & $71 \mathrm{ab}$ & $63 \mathrm{a}$ & $61 \mathrm{a}$ & $61 \mathrm{bcd}$ & $63 \mathrm{bc}$ & $61 \mathrm{bcde}$ \\
MM-2 & $60 \mathrm{de}$ & $62 \mathrm{e}$ & $60 \mathrm{~cd}$ & $58 \mathrm{~b}$ & $59 \mathrm{de}$ & $60 \mathrm{de}$ & $60 \mathrm{efg}$ \\
MM-3 & $66 \mathrm{a}$ & $71 \mathrm{a}$ & $64 \mathrm{a}$ & $61 \mathrm{a}$ & $63 \mathrm{a}$ & $66 \mathrm{~b}$ & $60 \mathrm{de}$ \\
MM-4 & $62 \mathrm{~cd}$ & $68 \mathrm{c}$ & $60 \mathrm{~d}$ & $58 \mathrm{~b}$ & $60 \mathrm{cde}$ & $62 \mathrm{~cd}$ & $61 \mathrm{defg}$ \\
MM-5 & $63 \mathrm{bc}$ & $72 \mathrm{a}$ & $63 \mathrm{a}$ & $59 \mathrm{ab}$ & $62 \mathrm{abc}$ & $64 \mathrm{ab}$ & $63 \mathrm{abcd}$ & $61 \mathrm{~cd}$ \\
Numbu & $58 \mathrm{ef}$ & $60 \mathrm{ef}$ & $59 \mathrm{~d}$ & $58 \mathrm{~b}$ & $58 \mathrm{e}$ & $59 \mathrm{e}$ & $59 \mathrm{~g}$ \\
Super 1 & $57 \mathrm{f}$ & $59 \mathrm{f}$ & $60 \mathrm{bcd}$ & $58 \mathrm{~b}$ & $58 \mathrm{e}$ & $59 \mathrm{e}$ & $59 \mathrm{fg}$ \\
\hline
\end{tabular}

Note: BTB: Bontobili, South Sulawesi; MRS: Maros, South Sulawesi; LTM: East Lombok, West Nusa Tenggara; PKL: Pekalongan, Central Java, GKL: Gunungkidul, Yogyakarta; BTL: Bantul, Yogyakarta; mean values in the same column followed by different alphabet are significantly different based on LSD test at $\alpha$ \%.

Table 5. Strain $\mathrm{x}$ environment interaction on the plant height $(\mathrm{cm})$ of sweet sorghum mutant and two check varieties cultivated in eight study sites during 2017

\begin{tabular}{|c|c|c|c|c|c|c|c|c|}
\hline Strain & BTB & MRS & MLG & LTM & PKL & LMP & GKL & BTL \\
\hline MB-1 & $240.4 b$ & $285.7 \mathrm{~cd}$ & $242.1 \mathrm{~cd}$ & 277.8def & 295.0cde & 283.6de & $214.9 \mathrm{e}$ & 232.6def \\
\hline MB-2 & $235.0 \mathrm{bc}$ & $274.9 \mathrm{de}$ & $228.5 \mathrm{ef}$ & $271.5 \mathrm{fg}$ & $270.9 f$ & $284.8 \mathrm{cde}$ & 219.8de & $237.1 \mathrm{de}$ \\
\hline MB-3 & $240.2 b$ & $293.2 \mathrm{c}$ & $251.3 c$ & $295.0 \mathrm{c}$ & $310.2 \mathrm{ab}$ & 290.6bcde & $231.2 \mathrm{~cd}$ & 230.2efg \\
\hline MB-4 & $243.6 b$ & $285.8 \mathrm{~cd}$ & $237.2 \mathrm{de}$ & $286.3 \mathrm{~cd}$ & $307.4 \mathrm{ab}$ & $301.7 \mathrm{ab}$ & $237.0 \mathrm{c}$ & $243.3 \mathrm{~cd}$ \\
\hline MB-5 & $242.9 \mathrm{~b}$ & $293.8 c$ & $245.0 \mathrm{~cd}$ & $285.5 \mathrm{cde}$ & $312.7 \mathrm{a}$ & $264.9 f$ & $236.7 \mathrm{c}$ & $237.1 \mathrm{de}$ \\
\hline MM-1 & $237.4 \mathrm{bc}$ & $280.2 \mathrm{~d}$ & $245.5 \mathrm{~cd}$ & 273.6ef & 298.9bcde & $302.7 \mathrm{ab}$ & 221.4de & 241.4de \\
\hline MM-2 & $226.9 \mathrm{~cd}$ & $267.2 \mathrm{e}$ & 228.6ef & $260.3 \mathrm{~g}$ & $291.0 \mathrm{e}$ & $281.0 \mathrm{e}$ & $214.6 \mathrm{e}$ & $224.6 \mathrm{fg}$ \\
\hline MM-3 & $258.4 \mathrm{a}$ & $314.3 b$ & 281.b & $316.3 \mathrm{~b}$ & $305.5 \mathrm{abc}$ & $285.3 \mathrm{cde}$ & $253.6 \mathrm{~b}$ & $254.1 \mathrm{bc}$ \\
\hline MM-4 & $240.3 b$ & $279.8 \mathrm{~d}$ & $237.0 \mathrm{de}$ & $246.0 \mathrm{~h}$ & $287.2 \mathrm{e}$ & 294.4abcd & $215.3 \mathrm{e}$ & $237.3 \mathrm{de}$ \\
\hline MM-5 & $258.2 \mathrm{a}$ & $311.0 \mathrm{~b}$ & $279.3 b$ & $310.0 \mathrm{~b}$ & $304.2 \mathrm{abcd}$ & $296.5 \mathrm{abc}$ & $239.4 \mathrm{c}$ & $262.3 b$ \\
\hline Numbu & $218.4 d$ & 248.1f & $217.1 \mathrm{f}$ & $221.5 \mathrm{i}$ & $294.2 \mathrm{cde}$ & $244.1 \mathrm{~g}$ & $216.1 \mathrm{e}$ & $218.2 \mathrm{~g}$ \\
\hline Super 1 & $236.9 b c$ & $331.6 \mathrm{a}$ & $313.2 \mathrm{a}$ & $331.6 \mathrm{a}$ & $292.8 \mathrm{de}$ & $305.9 \mathrm{a}$ & $270.6 a$ & $281.2 \mathrm{a}$ \\
\hline
\end{tabular}

Note: BTB: Bontobili, South Sulawesi; MRS: Maros, South Sulawesi; LTM: East Lombok, West Nusa Tenggara; PKL: Pekalongan, Central Java, GKL: Gunungkidul, Yogyakarta; BTL: Bantul, Yogyakarta; mean values in the same column followed by different alphabet are significantly different based on LSD test at $\alpha$ 5\%.

The flowering age of sweet sorghum mutant and two check varieties were significantly affected by the interaction of genetics and environment (Table 4). The range of flowering age in Numbu and Super 1 in eight study sites was 58-60 days and 57-60 days, respectively. The range of flowering age in all tested mutant that cultivated in eight study sites were 61-65 days (MB-1), 5871 days (MB-2), 62-71 days (MB-3), 61-70 days (MB-4), 59-69 days (MB-4), 58-71 days (MM-1), 58-62 days (MM2), 61-71 days (MM-3), 58-68 days (MM-4) and 59-72 days (MM-5). The shortest variation of flowering age among all tested mutant strain was found in MB-1, while the longest one was found in MB-2 and MM-5. In general, the flowering age of sweet sorghum mutant was longer than two check varieties in all study sites. All mutant strains cultivated in Maros had significantly different and longer flowering age than two check varieties, while in East Lombok study site, most of sweet sorghum mutant strain tended to have similar or no significant different of flowering age than Numbu and Super 1. This finding indicated that the interaction between genotypes and the environment ( $\mathrm{G} \times \mathrm{E}$ ) occurred when genotypes showed different responses to different environmental conditions (Yuliasti 2016).

The plant height of sweet sorghum was also significantly affected by the interaction of genetic $\mathrm{x}$ environment (Table 5). The Super 1 was the highest sorghum variety than Numbu and other mutant strain tested, in most of the study sites, except in Bontobili and Pekalongan. In Botobili, the highest plant was recorded in mutant strain namely MM-3, while in Pekalongan the highest one was MB-5. However, compared to the elder (Numbu), the obtained mutant showed an improvement of plant height. Among the variation of sorghum plant height as the effect of $\mathrm{G} \times \mathrm{E}$ interaction, the highest mutant plant was MM-3 that cultivated in East Lombok, i.e. $316.3 \mathrm{~cm}$, while the lowest mutant plant was MM-2 that cultivated in Gunungkidul, i.e. $214.6 \mathrm{~cm}$. Those finding was indicated 
the presence of an interaction between genotypes and environment, thus each strain had different results in different environments (Yuliasti 2016). Genotype $x$ environment interactions were caused by the changes in the response of each genotype in each environment (Mut et al. 2010).

The radar chart could be used to ease the understanding of the result variation among 8 study sites. Based on the chart, sweet sorghum mutant strain of MM-2 and MB-1 relatively more stable than other mutant strains in terms of flowering age. It was indicated by a short distance of plot position between the lowest result compared to the highest one within the same variety. Moreover, Numbu and Super1 as sorghum check varieties also showed stable and relatively similar flowering age, irrespective of growing locations (Figure 1.A). Based on the radar chart of plant height (Figure 1.B), there was a lot of variation resulted in all tested sorghum, indicated by a high distance of plot position between the lowest result compared to the highest one within the same variety. Unlike the flowering age that could show which one was stable than others, the plant height of all tested sorghum seemed to be unstable as the effect of interaction between genetic and growing location. However, there was a tendency that sorghum cultivated in Pekalongan showed the highest result, while those on Gunungkidul showed the opposite result. It was likely that the variation of environmental conditions such as water availability, soil fertility, and microclimate could determine the agronomic character of the plant.

Stem diameter was one of important characters because of its role to determine the plant biomass resulted (Pabendon et al. 2012). Stem diameter of sweet sorghum was affected by the interaction of $\mathrm{G} \times \mathrm{E}$ (Table 6). The lowest stem diameter was recorded in MB-2 strain in Pekalongan, while the largest stem diameter was found in MB-5 strain cultivated in Malang. The mean value of stem diameter of tested sorghum mutant cultivated in Pekalongan was the lowest compared to others, while in Malang vice versa. There were different responses from each strain in different environments in terms of stem diameter character. The mutant strain of MM-1 showed the smallest stem compared to all mutants, while the MB-5 show the opposite. However, all tested mutants possessed largest diameter of stem compared to two check varieties. The results revealed the desired effect of the random mutation through gamma irradiation on the improvement of stem size.

The panicle length was the important agronomic character for sorghum breeding, because the panicle was the part of seed growth and development. The panicle length was also the agronomic characters that was affected by the genetic factor and also adaptation capability to the specific environmental condition. Similar to previous report by Anasari et al. (2017) that plant performance was strongly governed either by genetics, environment or interaction of $\mathrm{G} \times \mathrm{E}$. Panicle length of sweet sorghum cultivated in Bontobili, Maros, Malang, Lampung and Bantul was not significantly different to the elder (Numbu) but it was significantly lower than Super 1 check variety. In opposite, cultivation of mutant strain in East Lombok and Pekalongan had longer panicle than two check variety, i.e MM-4 in East Lombok and MB-3 in Pekalongan (Table 7).

The radar chart of Figure 2.A showed the variation of stem diameter and panicle length as affected by the interaction of genetics and environment. In term of stem diameter, there was a relatively small variation of stem diameter in MM-1 strain compared to other mutants. It was indicated by a short plot distance between the highest result and the lowest one within the same strain. It was likely that stem diameter of MM-1 showed almost similar results in 8 growing locations. Additionally, two check varieties, namely Numbu and Super1, also showed lower variation than mutant strains, except MM-1 (Figure 2.A). In terms of panicle length, sweet sorghum mutant strain of MB-1 and MM-2 and were relatively more stable than other mutant strains. In opposite, the panicle length of Super1, MM-4 and MB-5 seemed to have a lot of variation among 8 study sites (Figure 2.B). This finding indicated the big influence of genetic factors on the stem diameter and panicle length of sweet sorghum.

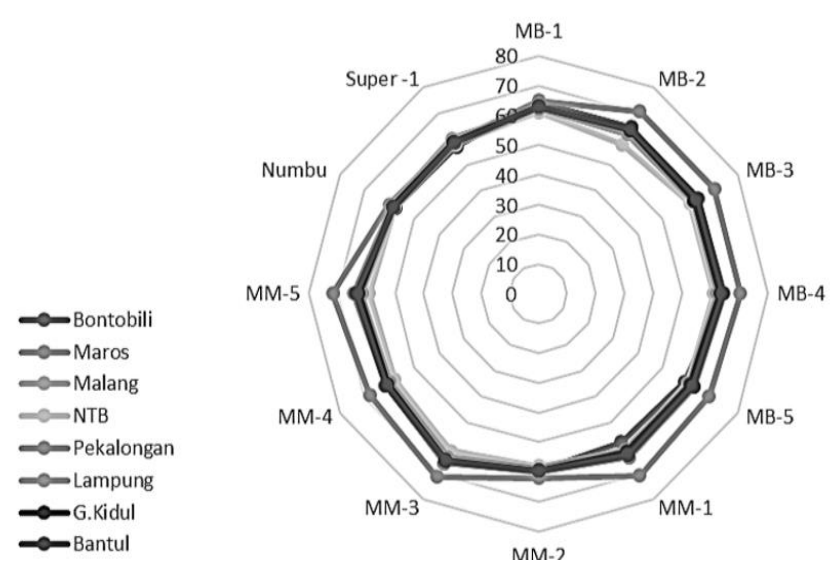

A

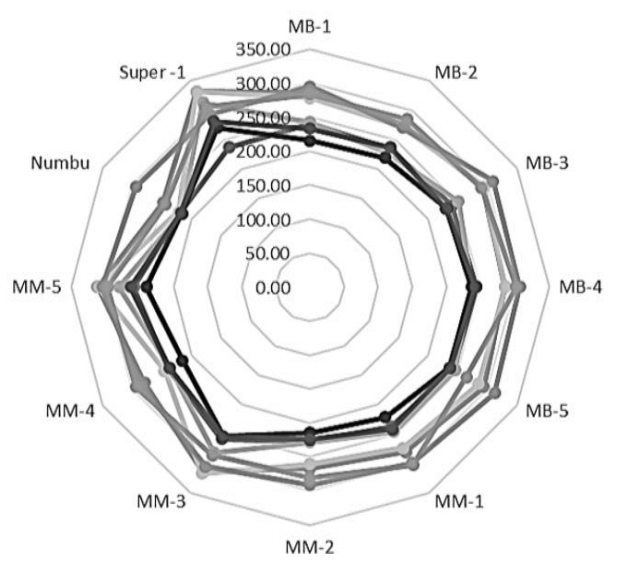

B

Figure 1. Radar chart of strain x environment interaction on flowering age (A) and plant height (B) of sweet sorghum mutant and two check varieties cultivated in eight study sites during 2017 

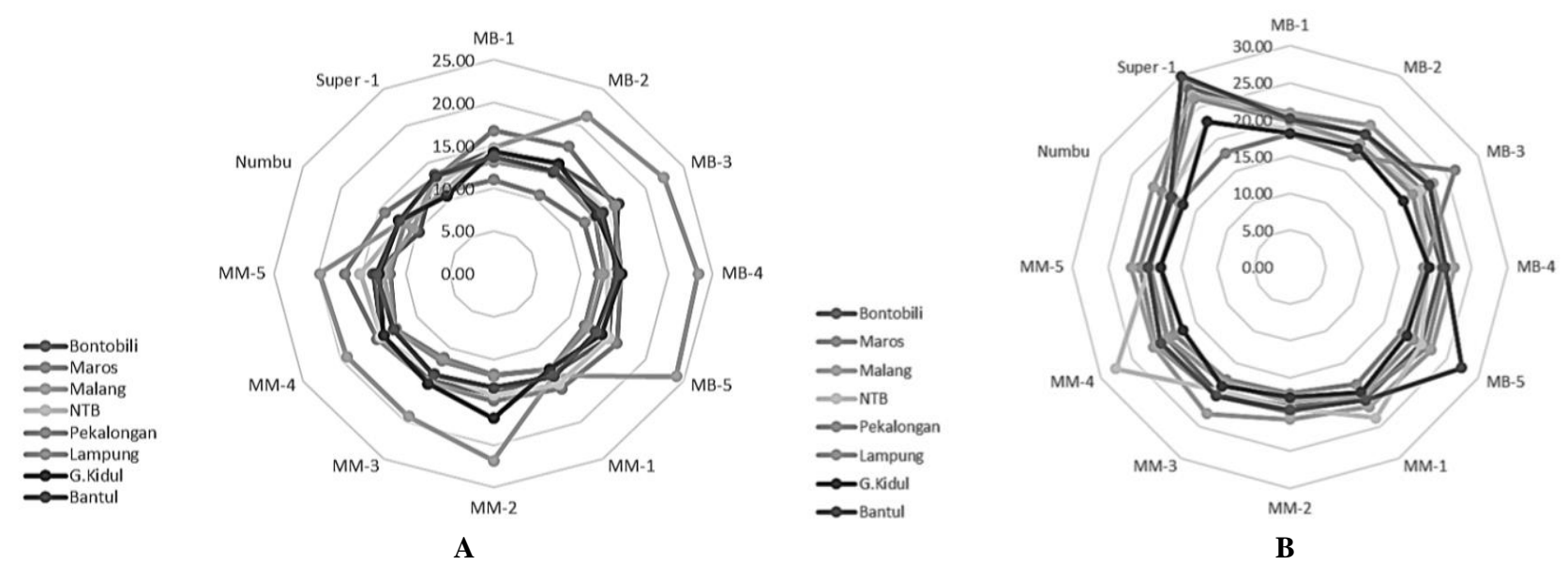

Figure 2. Radar chart of strain $\mathrm{x}$ environment interaction on stem diameter (A) and panicle length (B) of sweet sorghum mutants and two check varieties cultivated in eight study sites during 2017

Table 6. Strain $\mathrm{x}$ environment interaction on stem diameter $(\mathrm{mm})$ of sweet sorghum mutant and two check varieties cultivated in eight study sites during 2017

\begin{tabular}{lllllllll}
\hline Strain & BTB & MRS & MLG & LTM & PKL & LMP & GKL & BTL \\
\hline MB-1 & $14.3 \mathrm{bc}$ & $16.7 \mathrm{ab}$ & $14.7 \mathrm{e}$ & $14.4 \mathrm{ab}$ & $11.0 \mathrm{~b}$ & $13.1 \mathrm{abc}$ & $14.2 \mathrm{bcd}$ & $13.6 \mathrm{ab}$ \\
MB-2 & $14.7 \mathrm{bc}$ & $17.1 \mathrm{a}$ & $21.3 \mathrm{c}$ & $14.6 \mathrm{ab}$ & $10.7 \mathrm{~b}$ & $13.6 \mathrm{a}$ & $14.9 \mathrm{~b}$ & $13.8 \mathrm{a}$ \\
MB-3 & $16.4 \mathrm{a}$ & $15.9 \mathrm{abcd}$ & $22.5 \mathrm{bc}$ & $14.6 \mathrm{ab}$ & $12.0 \mathrm{ab}$ & $13.3 \mathrm{ab}$ & $13.6 \mathrm{bcde}$ & $14.4 \mathrm{a}$ \\
MB-4 & $13.7 \mathrm{bc}$ & $14.5 \mathrm{de}$ & $23.3 \mathrm{ab}$ & $13.0 \mathrm{cde}$ & $11.9 \mathrm{ab}$ & $12.6 \mathrm{abc}$ & $14.6 \mathrm{~b}$ & $14.3 \mathrm{a}$ \\
MB-5 & $15.1 \mathrm{ab}$ & $16.2 \mathrm{abc}$ & $24.1 \mathrm{a}$ & $15.1 \mathrm{a}$ & $12.0 \mathrm{ab}$ & $12.6 \mathrm{abc}$ & $14.2 \mathrm{bcd}$ & $13.5 \mathrm{ab}$ \\
MM-1 & $13.4 \mathrm{c}$ & $15.5 \mathrm{bcde}$ & $13.8 \mathrm{e}$ & $14.9 \mathrm{a}$ & $13.0 \mathrm{a}$ & $12.9 \mathrm{abc}$ & $12.9 \mathrm{de}$ & $13.9 \mathrm{a}$ \\
MM-2 & $14.1 \mathrm{bc}$ & $14.8 \mathrm{cde}$ & $21.9 \mathrm{c}$ & $14.2 \mathrm{abc}$ & $11.8 \mathrm{ab}$ & $12.0 \mathrm{bcd}$ & $16.9 \mathrm{a}$ & $13.3 \mathrm{ab}$ \\
MM-3 & $14.4 \mathrm{bc}$ & $14.6 \mathrm{de}$ & $19.3 \mathrm{~d}$ & $13.4 \mathrm{bcd}$ & $11.4 \mathrm{~b}$ & $11.8 \mathrm{~cd}$ & $14.8 \mathrm{~b}$ & $13.6 \mathrm{ab}$ \\
MM-4 & $14.7 \mathrm{bc}$ & $15.3 \mathrm{cde}$ & $19.3 \mathrm{~d}$ & $14.8 \mathrm{ab}$ & $12.9 \mathrm{a}$ & $13.1 \mathrm{~cd}$ & $14.4 \mathrm{bc}$ & $13.1 \mathrm{ab}$ \\
MM-5 & $13.7 \mathrm{bc}$ & $16.9 \mathrm{a}$ & $19.8 \mathrm{~d}$ & $15.2 \mathrm{a}$ & $11.8 \mathrm{ab}$ & $12.6 \mathrm{abc}$ & $13.0 \mathrm{cde}$ & $13.3 \mathrm{ab}$ \\
Numbu & $9.7 \mathrm{~d}$ & $14.3 \mathrm{ef}$ & $12.1 \mathrm{f}$ & $11.9 \mathrm{e}$ & $11.7 \mathrm{ab}$ & $10.6 \mathrm{~d}$ & $12.4 \mathrm{e}$ & $12.4 \mathrm{~b}$ \\
Super 1 & $13.4 \mathrm{c}$ & $13.0 \mathrm{f}$ & $11.1 \mathrm{f}$ & $12.2 \mathrm{de}$ & $11.1 \mathrm{~b}$ & $13.2 \mathrm{ab}$ & $10.5 \mathrm{f}$ & $13.2 \mathrm{ab}$ \\
\hline
\end{tabular}

Note: BTB: Bontobili, South Sulawesi; MRS: Maros, South Sulawesi; LTM: East Lombok, West Nusa Tenggara; PKL: Pekalongan, Central Java, GKL: Gunungkidul, Yogyakarta; BTL: Bantul, Yogyakarta; mean values in the same column followed by different alphabet are significantly different based on LSD test at $\alpha$ 5\%.

Table 7. Strain $x$ environment interaction on panicle length $(\mathrm{cm})$ of sweet sorghum mutant and two check varieties cultivated in eight study sites during 2017

\begin{tabular}{lllllllll}
\hline Strain & BTB & MRS & MLG & LTM & PKL & LMP & GKL & BTL \\
\hline MB-1 & $20.01 \mathrm{~b}$ & $20.66 \mathrm{~b}$ & $20.92 \mathrm{~b}$ & $18.78 \mathrm{dcd}$ & $18.07 \mathrm{~b}$ & $19.77 \mathrm{~b}$ & $18.13 \mathrm{~b}$ & $20.13 \mathrm{~b}$ \\
MB-2 & $18.72 \mathrm{~b}$ & $20.71 \mathrm{~b}$ & $22.16 \mathrm{~b}$ & $19.13 \mathrm{~cd}$ & $17.35 \mathrm{~b}$ & $19.23 \mathrm{~b}$ & $18.60 \mathrm{~b}$ & $20.80 \mathrm{~b}$ \\
MB-3 & $20.67 \mathrm{~b}$ & $20.96 \mathrm{~b}$ & $22.69 \mathrm{~b}$ & $20.64 \mathrm{bcd}$ & $26.23 \mathrm{a}$ & $19.57 \mathrm{~b}$ & $18.00 \mathrm{~b}$ & $22.19 \mathrm{~b}$ \\
MB-4 & $20.91 \mathrm{~b}$ & $21.45 \mathrm{~b}$ & $22.63 \mathrm{~b}$ & $19.01 \mathrm{~cd}$ & $\mathrm{a} 18.45 \mathrm{~b}$ & $19.07 \mathrm{~b}$ & $19.13 \mathrm{ab}$ & $21.35 \mathrm{~b}$ \\
MB-5 & $20.92 \mathrm{~b}$ & $21.77 \mathrm{~b}$ & $22.48 \mathrm{~b}$ & $20.86 \mathrm{bcd}$ & $17.88 \mathrm{~b}$ & $19.70 \mathrm{~b}$ & $18.60 \mathrm{~b}$ & $27.31 \mathrm{a}$ \\
MM-1 & $20.69 \mathrm{~b}$ & $20.14 \mathrm{~b}$ & $21.87 \mathrm{~b}$ & $23.65 \mathrm{~b}$ & $18.33 \mathrm{~b}$ & $19.87 \mathrm{~b}$ & $19.60 \mathrm{ab}$ & $20.87 \mathrm{~b}$ \\
MM-2 & $18.90 \mathrm{~b}$ & $19.70 \mathrm{~b}$ & $20.70 \mathrm{~b}$ & $19.12 \mathrm{~cd}$ & $17.15 \mathrm{~b}$ & $18.23 \mathrm{~b}$ & $17.70 \mathrm{~b}$ & $19.37 \mathrm{~b}$ \\
MM-3 & $19.84 \mathrm{~b}$ & $20.19 \mathrm{~b}$ & $22.95 \mathrm{~b}$ & $19.32 \mathrm{~cd}$ & $17.63 \mathrm{~b}$ & $18.20 \mathrm{~b}$ & $18.67 \mathrm{~b}$ & $20.18 \mathrm{~b}$ \\
MM-4 & $19.44 \mathrm{~b}$ & $21.29 \mathrm{~b}$ & $21.65 \mathrm{~b}$ & $27.68 \mathrm{a}$ & $18.40 \mathrm{~b}$ & $19.47 \mathrm{~b}$ & $17.03 \mathrm{~b}$ & $20.58 \mathrm{~b}$ \\
MM-5 & $19.59 \mathrm{~b}$ & $20.67 \mathrm{~b}$ & $21.86 \mathrm{~b}$ & $19.34 \mathrm{~cd}$ & $17.88 \mathrm{~b}$ & $19.27 \mathrm{~b}$ & $17.80 \mathrm{~b}$ & $19.55 \mathrm{~b}$ \\
Numbu & $18.65 \mathrm{~b}$ & $20.35 \mathrm{~b}$ & $21.74 \mathrm{~b}$ & $19.14 \mathrm{~cd}$ & $17.53 \mathrm{~b}$ & $19.10 \mathrm{~b}$ & $17.00 \mathrm{~b}$ & $18.98 \mathrm{~b}$ \\
Super 1 & $28.10 \mathrm{a}$ & $29.28 \mathrm{a}$ & $26.98 \mathrm{a}$ & $22.70 \mathrm{bc}$ & $17.85 \mathrm{~b}$ & $26.40 \mathrm{a}$ & $22.77 \mathrm{a}$ & $29.86 \mathrm{a}$ \\
\hline
\end{tabular}

Note: BTB: Bontobili, South Sulawesi; MRS: Maros, South Sulawesi; LTM: East Lombok, West Nusa Tenggara; PKL: Pekalongan, Central Java, GKL: Gunungkidul, Yogyakarta; BTL: Bantul, Yogyakarta; mean values in the same column followed by different alphabet are significantly different based on LSD test at $\alpha 5 \%$ 
The sugar content in sweet sorghum is an important character in sorghum development as raw material either for liquid sugar or for bioethanol. The sugar content was also influenced by genetic and environmental factors (DeLacy et al. 2010; Pabendon et al. 2017). Similar result was proved in this work. The sugar Brix of sweet sorghum mutant strain ranged between $7.09 \%$ (MB-5 cultivated in Bontobili) - 18.69\% (MM-2 cultivated in Maros) (Table 8). In general, the sweet sorghum planted in Maros was the sweetest, while in Pekalongan was the lowest sugar brix. This finding indicated that environmental conditions, aside from the genetic factors, in Maros were more suitable than in Pekalongan for sweet sorghum plantation. The average value of sugar brix in all tested mutant strains was $15.3 \%$ and it was higher than Numbu as the elder, i.e $14.3 \%$ or Super 1 as another check variety, i.e $13.6 \%$.

The increase of sugar brix was associated with the increase of the stem juice volume of sweet sorghum. The highest juice content was recorded in MM-4 strain cultivated in Maros, while the lowest one was MM-2 strain cultivated in Lampung (Table 9). In general, stem juice content of all tested mutant strains in 8 study sites were 120 $\mathrm{ml}$, and it was higher than two check varieties, i.e Numbu $(84.6 \mathrm{ml})$ and Super 1 (92.5 ml). Maros environmental condition supported the highest juice content of sweet sorghum than others, while in Lampung was the opposite occurred. Factors affecting the juice content was the interaction of genetic and environmental condition (Pabendon et al. 2017). The highest sugar brix and stem juice characters of sweet sorghum on Maros might be supported by the good soil fertility and optimal climatic conditions.

The radar chart of Figure 3 showed the variation of sugar brix and stem juice volume of tested sweet sorghum genotypes. Based on the chart, the MB-2 seemed to be the most stable strain in term of sugar brix compared to other mutant strains and even check varieties, while a lot of variation (relatively unstable result among 8 locations) was showed either by Super 1 and MB-5 (Figure 3.A). In terms of stem juice volume (Figure 3.B), there was a lot of variation resulted in all tested sorghum, indicated by a high distance of plot position between the lowest result compared to the highest one within the same variety (the same axe). Unlike the sugar brix that could show which one was stable than others, the stem juice volume of all tested sorghum seemed to be unstable as the effect of interaction between genetic and growing location. There was a tendency that sorghum cultivated in Maros showed the highest result, while those cultivated on Lampung showed the lowest one. This result might be associated with different growing location characters between both locations, especially in terms of soil fertility and climate condition.

The seed weight per panicle was one of yield components that significantly affected by the interaction of $\mathrm{G} \times \mathrm{E}$ (Table 10). The heaviest seed per panicle was found in MM-4 strain cultivated in Malang, while the lowest one was found both in MM-2 strain in Bontobili and MB-3 in Pekalongan. This finding showed that the tested mutant lines have different responses in form of seed weight at different locations. It also indicated the success of mutations to produce a wide diversity of seed weight characters in sweet sorghum cultivated in various growing environments. The average of seed weight per panicle of Numbu and Super 1 was $0.076 \mathrm{~g}$ and $0.0056 \mathrm{~g}$, while all tested mutant showed better, i.e $0.079 \mathrm{~g}$ (Table 9). However, the result of mutant only significantly different from Super 1 and was not significant compared to the elder Numbu.
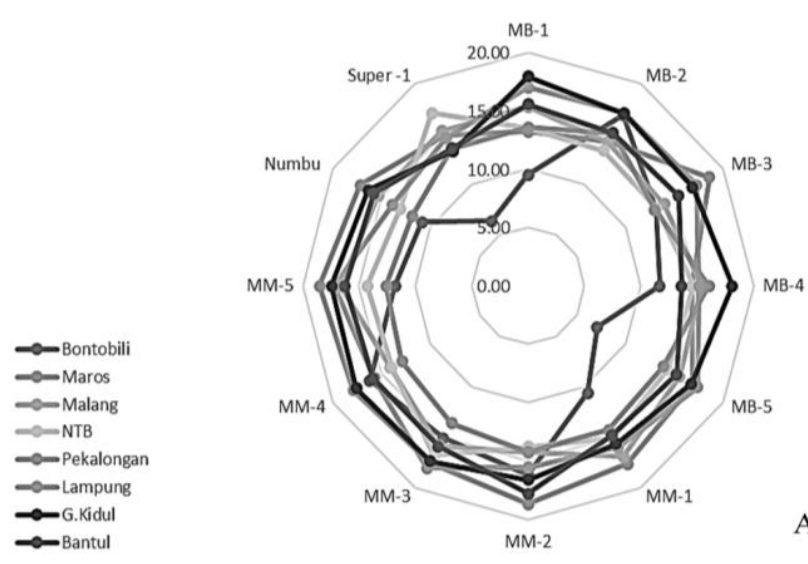

A

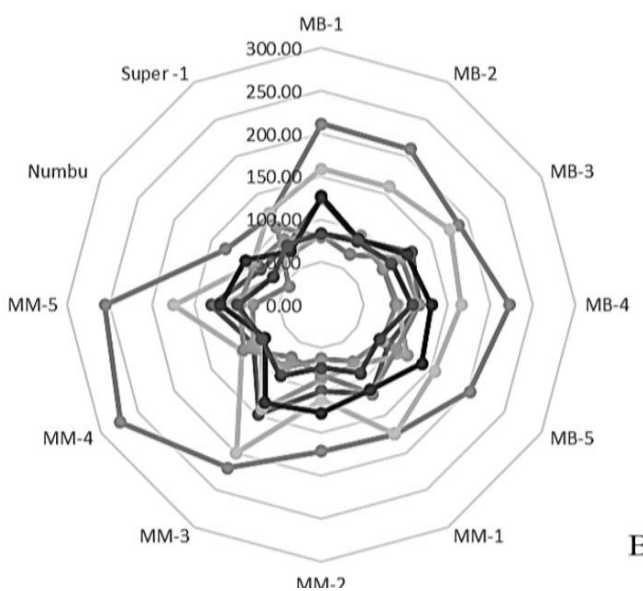

B

Figure 3. Radar chart of strain $x$ environment interaction on sugar brix (A) and stem juice volume (B) of sweet sorghum mutant and two check varieties cultivated in eight study sites during 2017 
Table 8. Strain x environment interaction on sugar brix (\%) of sweet sorghum mutant and two check varieties cultivated in eight study sites during 2017

\begin{tabular}{lllllllll}
\hline Strain & BTB & MRS & MLG & LTM & PKL & LMP & GKL & BTL \\
\hline MB-1 & $9.51 \mathrm{a}$ & $13.18 \mathrm{e}$ & $15.33 \mathrm{bcde}$ & $13.49 \mathrm{~cd}$ & $13.55 \mathrm{~cd}$ & $16.97 \mathrm{abc}$ & $17.93 \mathrm{ab}$ & $15.55 \mathrm{bc}$ \\
MB-2 & $16.87 \mathrm{a}$ & $14.29 \mathrm{de}$ & $14.17 \mathrm{cde}$ & $13.36 \mathrm{~cd}$ & $15.08 \mathrm{ab}$ & $17.07 \mathrm{abc}$ & $17.00 \mathrm{abcd}$ & $15.07 \mathrm{bc}$ \\
MB-3 & $13.07 \mathrm{c}$ & $18.56 \mathrm{ab}$ & $13.96 \mathrm{e}$ & $13.18 \mathrm{~d}$ & $12.98 \mathrm{cde}$ & $17.23 \mathrm{ab}$ & $16.85 \mathrm{abcd}$ & $15.40 \mathrm{bc}$ \\
MB-4 & $11.68 \mathrm{~cd}$ & $14.52 \mathrm{de}$ & $15.40 \mathrm{bcd}$ & $14.67 \mathrm{bc}$ & $16.05 \mathrm{a}$ & $15.13 \mathrm{de}$ & $18.10 \mathrm{a}$ & $13.60 \mathrm{~d}$ \\
MB-5 & $7.09 \mathrm{f}$ & $16.86 \mathrm{c}$ & $15.50 \mathrm{abc}$ & $14.32 \mathrm{bcd}$ & $13.82 \mathrm{bcd}$ & $17.33 \mathrm{ab}$ & $16.73 \mathrm{abcd}$ & $15.20 \mathrm{bc}$ \\
MM-1 & $10.5 \mathrm{de} 9$ & $17.61 \mathrm{abc}$ & $16.90 \mathrm{a}$ & $15.05 \mathrm{~b}$ & $14.25 \mathrm{bc}$ & $15.97 \mathrm{bcd}$ & $15.63 \mathrm{~d}$ & $14.80 \mathrm{~cd}$ \\
MM-2 & $16.20 \mathrm{ab}$ & $18.69 \mathrm{aabc}$ & $14.29 \mathrm{cde}$ & $13.81 \mathrm{bcd}$ & $14.25 \mathrm{bc}$ & $15.53 \mathrm{~d}$ & $16.60 \mathrm{bcd}$ & $17.82 \mathrm{a}$ \\
MM-3 & $15.04 \mathrm{~b}$ & $17.46 \mathrm{abc}$ & $15.81 \mathrm{ab}$ & $16.73 \mathrm{a}$ & $13.60 \mathrm{~cd}$ & $18.00 \mathrm{a}$ & $17.35 \mathrm{abcd}$ & $15.90 \mathrm{bc}$ \\
MM-4 & $16.22 \mathrm{ab}$ & $17.91 \mathrm{abc}$ & $14.06 \mathrm{de}$ & $13.96 \mathrm{bcd}$ & $12.93 \mathrm{cde}$ & $15.75 \mathrm{~cd}$ & $17.58 \mathrm{abc}$ & $15.90 \mathrm{bc}$ \\
MM-5 & $11.78 \mathrm{~cd}$ & $18.49 \mathrm{ab}$ & $16.65 \mathrm{ab}$ & $14.26 \mathrm{bcd}$ & $12.58 \mathrm{de}$ & $17.18 \mathrm{ab}$ & $17.45 \mathrm{abc}$ & $16.25 \mathrm{~b}$ \\
Numbu & $10.87 \mathrm{de}$ & $17.20 \mathrm{bc}$ & $15.37 \mathrm{bcde}$ & $13.13 \mathrm{~d}$ & $11.90 \mathrm{e}$ & $13.90 \mathrm{e}$ & $16.35 \mathrm{~cd}$ & $15.80 \mathrm{bc}$ \\
Super 1 & $6.40 \mathrm{f}$ & $14.85 \mathrm{~d}$ & $15.31 \mathrm{bcde}$ & $17.06 \mathrm{a}$ & $13.58 \mathrm{~cd}$ & $14.60 \mathrm{de}$ & $13.33 \mathrm{e}$ \\
\hline
\end{tabular}

Note: BTB: Bontobili, South Sulawesi; MRS: Maros, South Sulawesi; LTM: East Lombok, West Nusa Tenggara; PKL: Pekalongan, Central Java, GKL: Gunung kidul, Yogyakarta; BTL: Bantul, Yogyakarta; mean values in the same column followed by different alphabet are significantly different based on LSD test at $\alpha$ \%.

Table 9. Strain $\mathrm{x}$ environment interaction on the stem juice volume $(\mathrm{ml})$ of sweet sorghum mutant and two check varieties cultivated in eight study sites during 2017

\begin{tabular}{lllllllll}
\hline Strain & BTB & MRS & MLG & LTM & PKL & LMP & GKL & BTL \\
\hline MB-1 & $124 \mathrm{~b}$ & $212 \mathrm{~cd}$ & $83 \mathrm{~cd}$ & $159 \mathrm{bc}$ & $82 \mathrm{def}$ & $79 \mathrm{bc}$ & $127 \mathrm{ab}$ & $83 \mathrm{bcd}$ \\
MB-2 & $88 \mathrm{de}$ & $210 \mathrm{~cd}$ & $89 \mathrm{c}$ & $160 \mathrm{bc}$ & $68 \mathrm{f}$ & $93 \mathrm{ab}$ & $88 \mathrm{de}$ & $86 \mathrm{bcd}$ \\
MB-3 & $123 \mathrm{~b}$ & $187 \mathrm{ef}$ & $85 \mathrm{~cd}$ & $176 \mathrm{~b}$ & $110 \mathrm{ab}$ & $84 \mathrm{~b}$ & $117 \mathrm{bc}$ & $96 \mathrm{abc}$ \\
MB-4 & $116 \mathrm{bc}$ & $223 \mathrm{c}$ & $91 \mathrm{c}$ & $166 \mathrm{bc}$ & $115 \mathrm{a}$ & $89 \mathrm{ab}$ & $131 \mathrm{ab}$ & $108 \mathrm{a}$ \\
MB-5 & $92 \mathrm{de}$ & $203 \mathrm{de}$ & $117 \mathrm{~b}$ & $155 \mathrm{c}$ & $103 \mathrm{abc}$ & $84 \mathrm{~b}$ & $138 \mathrm{a}$ & $79 \mathrm{cde}$ \\
MM-1 & $120 \mathrm{~b}$ & $175 \mathrm{f}$ & $81 \mathrm{cde}$ & $175 \mathrm{~b}$ & $120 \mathrm{a}$ & $77 \mathrm{bc}$ & $115 \mathrm{bc}$ & $92 \mathrm{abc}$ \\
MM-2 & $100 \mathrm{~cd}$ & $171 \mathrm{f}$ & $87 \mathrm{c}$ & $111 \mathrm{de}$ & $82 \mathrm{def}$ & $63 \mathrm{c}$ & $127 \mathrm{ab}$ & $74 \mathrm{de}$ \\
MM-3 & $148 \mathrm{a}$ & $220 \mathrm{~cd}$ & $141 \mathrm{a}$ & $200 \mathrm{a}$ & $71 \mathrm{ef}$ & $84 \mathrm{~b}$ & $132 \mathrm{ab}$ & $96 \mathrm{abc}$ \\
MM-4 & $93 \mathrm{de}$ & $274 \mathrm{a}$ & $81 \mathrm{cde}$ & $108 \mathrm{de}$ & $106 \mathrm{ab}$ & $93 \mathrm{ab}$ & $77 \mathrm{e}$ & $81 \mathrm{cde}$ \\
MM-5 & $130 \mathrm{~b}$ & $256 \mathrm{~b}$ & $115 \mathrm{~b}$ & $175 \mathrm{~b}$ & $96 \mathrm{bcd}$ & $81 \mathrm{~b}$ & $119 \mathrm{bc}$ & $99 \mathrm{ab}$ \\
Numbu & $82 \mathrm{e}$ & $130 \mathrm{~g}$ & $65 \mathrm{e}$ & $94 \mathrm{e}$ & $93 \mathrm{bcd}$ & $44 \mathrm{~d}$ & $104 \mathrm{~cd}$ & $65 \mathrm{e}$ \\
Super 1 & $80 \mathrm{e}$ & $120 \mathrm{~g}$ & $69 \mathrm{de}$ & $124 \mathrm{~d}$ & $88 \mathrm{cde}$ & $105 \mathrm{a}$ & $73 \mathrm{e}$ & $81 \mathrm{cde}$ \\
\hline
\end{tabular}

Note: BTB: Bontobili, South Sulawesi; MRS: Maros, South Sulawesi; LTM: East Lombok, West Nusa Tenggara; PKL: Pekalongan, Central Java, GKL: Gunungkidul, Yogyakarta; BTL: Bantul, Yogyakarta; mean values in the same column followed by different alphabet are significantly different based on LSD test at $\alpha 5 \%$.

Table 10. Strain $\mathrm{x}$ environment interaction on seed weight per panicles $(\mathrm{g})$ of sweet sorghum mutant and two check varieties cultivated in eight study sites during 2017

\begin{tabular}{lllllllll}
\hline Strain & BTB & MRS & MLG & LTM & PKI & LM & GKL & BTL \\
\hline MB-1 & $0.05 \mathrm{~cd}$ & $0.08 \mathrm{abcd}$ & $0.17 \mathrm{abc}$ & $0.09 \mathrm{bc}$ & $0.04 \mathrm{ab}$ & $0.05 \mathrm{cc}$ & $0.07 \mathrm{ab}$ & $0.10 \mathrm{ab}$ \\
MB-2 & $0.06 \mathrm{abc}$ & $0.08 \mathrm{abc}$ & $0.17 \mathrm{ab}$ & $0.08 \mathrm{bc}$ & $0.03 \mathrm{ab}$ & $0.06 \mathrm{~b}$ & $0.08 \mathrm{a}$ & $0.07 \mathrm{de}$ \\
MB-3 & $0.07 \mathrm{a}$ & $0.07 \mathrm{bcd}$ & $0.17 \mathrm{abcd}$ & $0.08 \mathrm{bc}$ & $0.03 \mathrm{~b}$ & $0.07 \mathrm{ab}$ & $0.06 \mathrm{ab}$ & $0.09 \mathrm{bcde}$ \\
MB-4 & $0.06 \mathrm{abc}$ & $0.08 \mathrm{abcd}$ & $0.14 \mathrm{ef}$ & $0.08 \mathrm{bc}$ & $0.04 \mathrm{ab}$ & $0.06 \mathrm{abc}$ & $0.06 \mathrm{ab}$ & $0.08 \mathrm{cde}$ \\
MB-5 & $0.06 \mathrm{abc}$ & $0.07 \mathrm{~cd}$ & $0.16 \mathrm{bcd}$ & $0.11 \mathrm{a}$ & $0.04 \mathrm{ab}$ & $0.06 \mathrm{abc}$ & $0.07 \mathrm{a}$ & $0.10 \mathrm{ab}$ \\
MM-1 & $0.07 \mathrm{ab}$ & $0.09 \mathrm{a}$ & $0.13 \mathrm{fg}$ & $0.09 \mathrm{ab}$ & $0.05 \mathrm{a}$ & $0.06 \mathrm{abc}$ & $0.06 \mathrm{ab}$ & $0.09 \mathrm{abc}$ \\
MM-2 & $0.03 \mathrm{~d}$ & $0.06 \mathrm{~d}$ & $0.16 \mathrm{abcd}$ & $0.08 \mathrm{bc}$ & $0.04 \mathrm{ab}$ & $0.06 \mathrm{abc}$ & $0.08 \mathrm{a}$ & $0.09 \mathrm{abcd}$ \\
MM-3 & $0.06 \mathrm{abc}$ & $0.09 \mathrm{abc}$ & $0.15 \mathrm{de}$ & $0.07 \mathrm{bc}$ & $0.04 \mathrm{ab}$ & $0.06 \mathrm{abc}$ & $0.06 \mathrm{ab}$ & $0.08 \mathrm{cde}$ \\
MM-4 & $0.05 \mathrm{abc}$ & $0.08 \mathrm{abc}$ & $0.18 \mathrm{a}$ & $0.08 \mathrm{bc}$ & $0.04 \mathrm{ab}$ & $0.08 \mathrm{a}$ & $0.06 \mathrm{ab}$ & $0.11 \mathrm{a}$ \\
MM-5 & $0.05 \mathrm{bcd}$ & $0.09 \mathrm{ab}$ & $0.15 \mathrm{cde}$ & $0.08 \mathrm{c}$ & $0.05 \mathrm{ab}$ & $0.07 \mathrm{ab}$ & $0.05 \mathrm{bc}$ & $0.08 \mathrm{cde}$ \\
Numbu & $0.06 \mathrm{abc}$ & $0.08 \mathrm{abcd}$ & $0.15 \mathrm{de}$ & $0.07 \mathrm{~d}$ & $0.04 \mathrm{ab}$ & $0.07 \mathrm{ab}$ & $0.07 \mathrm{ab}$ & $0.07 \mathrm{de}$ \\
Super 1 & $0.05 \mathrm{abc}$ & $0.03 \mathrm{e}$ & $0.12 \mathrm{~g}$ & 0.04 & $0.04 \mathrm{ab}$ & $0.06 \mathrm{bc}$ & $0.04 \mathrm{c}$ & $0.07 \mathrm{e}$ \\
\hline
\end{tabular}

Note: BTB: Bontobili, South Sulawesi; MRS: Maros, South Sulawesi; LTM: East Lombok, West Nusa Tenggara; PKL: Pekalongan, Central Java, GKL: Gunungkidul, Yogyakarta; BTL: Bantul, Yogyakarta; mean values in the same column followed by different alphabet are significantly different based on LSD test at $\alpha$ \% 
Table 11. Strain $x$ environment interaction on seed yield (ton per ha) of sweet sorghum mutant and two check varieties cultivated in eight study sites during 2017

\begin{tabular}{lllllllll}
\hline Strain & BTB & MRS & MLG & LTM & PKL & LMP & GKL & BTL \\
\hline MB-1 & $4.44 \mathrm{de}$ & $5.22 \mathrm{de}$ & $6.78 \mathrm{cde}$ & $7.04 \mathrm{c}$ & $10.39 \mathrm{a}$ & $5.09 \mathrm{e}$ & $5.84 \mathrm{bc}$ & $6.52 \mathrm{bcd}$ \\
MB-2 & $5.67 \mathrm{abc}$ & $5.55 \mathrm{~cd}$ & $8.10 \mathrm{a}$ & $8.18 \mathrm{~b}$ & $6.13 \mathrm{fg}$ & $5.48 \mathrm{cde}$ & $6.76 \mathrm{ab}$ & $6.52 \mathrm{bcd}$ \\
MB-3 & $6.68 \mathrm{a}$ & $6.41 \mathrm{bc}$ & $7.58 \mathrm{abc}$ & $6.91 \mathrm{c}$ & $9.26 \mathrm{~b}$ & $7.05 \mathrm{a}$ & $5.84 \mathrm{bc}$ & $6.22 \mathrm{~cd}$ \\
MB-4 & $5.47 \mathrm{bcd}$ & $6.99 \mathrm{ab}$ & $6.05 \mathrm{de}$ & $6.83 \mathrm{c}$ & $6.05 \mathrm{~g}$ & $6.63 \mathrm{ab}$ & $5.94 \mathrm{bc}$ & $8.30 \mathrm{a}$ \\
MB-5 & $5.49 \mathrm{bcd}$ & $5.78 \mathrm{~cd}$ & $8.00 \mathrm{ab}$ & $9.33 \mathrm{a}$ & $8.74 \mathrm{bc}$ & $5.52 \mathrm{bcde}$ & $6.88 \mathrm{ab}$ & $7.11 \mathrm{bc}$ \\
MM-1 & $5.92 \mathrm{ab}$ & $6.66 \mathrm{bc}$ & $6.17 \mathrm{de}$ & $7.16 \mathrm{bc}$ & $7.96 \mathrm{~cd}$ & $5.54 \mathrm{bcde}$ & $5.55 \mathrm{c}$ & $5.93 \mathrm{de}$ \\
MM-2 & $3.66 \mathrm{e}$ & $5.87 \mathrm{bcd}$ & $6.89 \mathrm{bcd}$ & $6.52 \mathrm{c}$ & $8.02 \mathrm{~cd}$ & $5.58 \mathrm{bcde}$ & $7.07 \mathrm{a}$ & $5.83 \mathrm{de}$ \\
MM-3 & $6.33 \mathrm{ab}$ & $6.52 \mathrm{bc}$ & $4.59 \mathrm{f}$ & $6.33 \mathrm{c}$ & $7.25 \mathrm{def}$ & $5.29 \mathrm{de}$ & $6.03 \mathrm{abc}$ & $6.07 \mathrm{cde}$ \\
MM-4 & $5.48 \mathrm{bcd}$ & $7.94 \mathrm{a}$ & $8.34 \mathrm{a}$ & $6.76 \mathrm{c}$ & $7.44 \mathrm{de}$ & $6.79 \mathrm{a}$ & $5.54 \mathrm{c}$ & $7.56 \mathrm{ab}$ \\
MM-5 & $4.56 \mathrm{cde}$ & $7.84 \mathrm{a}$ & $6.40 \mathrm{de}$ & $6.71 \mathrm{c}$ & $9.30 \mathrm{ab}$ & $6.48 \mathrm{abc}$ & $5.40 \mathrm{c}$ & $5.04 \mathrm{e}$ \\
Numbu & $4.47 \mathrm{de}$ & $4.21 \mathrm{e}$ & $5.75 \mathrm{e}$ & $6.34 \mathrm{c}$ & $4.84 \mathrm{~h}$ & $6.32 \mathrm{abcd}$ & $6.89 \mathrm{ab}$ & $5.63 \mathrm{de}$ \\
Super 1 & $4.47 \mathrm{de}$ & $1.32 \mathrm{f}$ & $6.14 \mathrm{de}$ & $4.15 \mathrm{~d}$ & $6.73 \mathrm{efg}$ & $6.25 \mathrm{abcd}$ & $3.56 \mathrm{~d}$ & $5.63 \mathrm{de}$ \\
\hline
\end{tabular}

Note: BTB: Bontobili, South Sulawesi; MRS: Maros, South Sulawesi; LTM: East Lombok, West Nusa Tenggara; PKL: Pekalongan, Central Java, GKL: Gunungkidul, Yogyakarta; BTL: Bantul, Yogyakarta; mean values in the same column followed by different alphabet are significantly different based on LSD test at $\alpha$ \%.

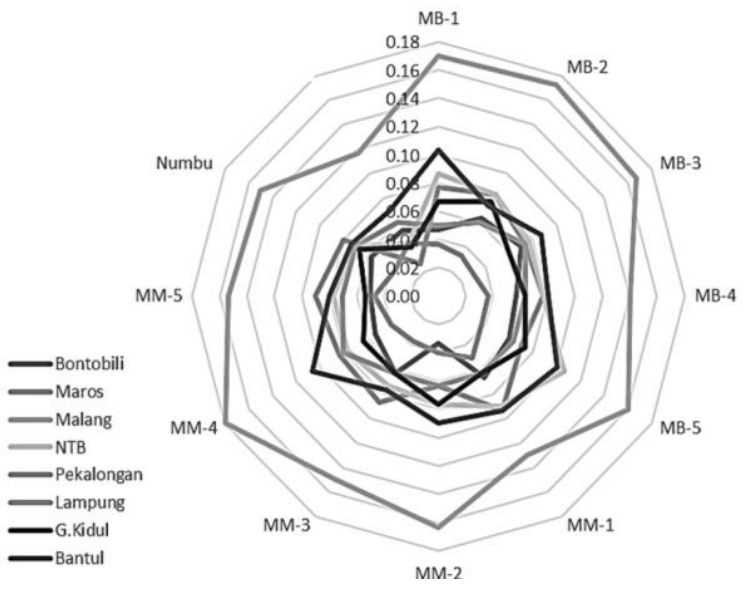

A

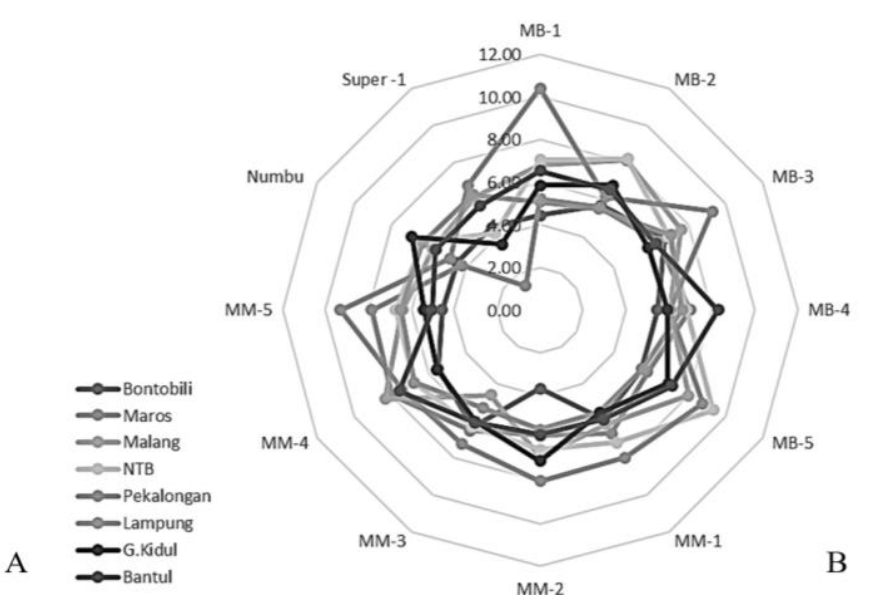

B

Figure 4. Radar chart of strain $x$ environment interaction on seed weight per panicle (A) and seed yield (B) of sweet sorghum mutant and two check varieties cultivated in eight study sites during 2017

The seed yield was important character that influenced the income of sorghum farmers. The farmer would like to use the genotype with a high yield and stable in various environmental conditions. The yield of sweet sorghum mutant and two check varieties were significantly affected by the interaction of genetics and environment (G x E). On average, seed yield sweet sorghum planted in Pekalongan have the best yield, while in Bontobili vice versa. The mutant strain had better yield than two check varieties. The average of seed yield on two check varieties in eight study sites were 5.56 ton per ha and 4.78 ton per ha, respectively, while the mutant strain had 6.56 ton per ha. The range of seed yield in eight study sites were 4.2-6.9 ton per ha in Numbu and 1.3-6.73 ton per ha in Super 1, respectively (Table 11). The range of seed yield (ton per ha) in all tested mutant that cultivated in eight study sites were 4.4-10.4 (MB-1), 5.5-8.2 (MB-2), 5.8-9.3 (MB-3), 5.5-8.3 (MB-4), 5.5-9.3 (MB-4) 5, 5.5-8 (MM-1), 3.7-8 days (MM-2), 4.6-
7.3 (MM-3), 5.5-8.3 days (MM-4) and 4.6-9.3 (MM-5) (Table 3). There was a lot of variation in term seed yield in all tested sorghum materials.

The radar chart of Figure 4 showed the variation of seed weight per panicle and seed yield as affected by the interaction of genetics and environment. There was a high variation (relatively unstable results) of seed weight per panicle and seed yield of sweet sorghum among 8 growing locations. It was indicated by a large plot distance between the highest result and the lowest one within the same variety (axe). In general, sweet sorghum cultivated in Malang could produce the highest number of seeds per panicle compared to other sites, while the opposite result showed by sorghum in Pekalongan. In terms of seed yield, the MB-1 strain showed great potential yield, however, the result was still varied according to the locations.

The new desired characters could be obtained by using the mutation technique (Cheema and Khalsa 2018). 
Mutations in soybean seeds carried out by Mudibu et al. (2012) produce new $\mathrm{M}_{2}$ mutants with higher seed production. Mutation that had conducted in rice by previous studies aimed to get disease-tolerant mutants (Lestari et al. 2017, Kharkwal et al. 2004). The modification of plant characters as the consequences of mutation treatment could be observed since the population of $\mathrm{M}_{2}$ mutants. The selection of mutants in the subsequent generation namely $\mathrm{M}_{3}, \mathrm{M}_{4}$, etc. showed a stable superior character. Previous study has produced drought-tolerant sorghum mutants by using the irradiation technique on the Dura variety, and putative mutants tolerant to acid soils with sugar Brix for about 10.50-11.95\% (Human and Sihono 2010). Wanga et al. (2018) used the irradiation techniques to induce the mutation and subsequently obtained the drought-tolerant new varieties of local sorghum in Namibia. This work with a number of sorghum mutant strains produced by the irradiation technique combined with in vitro showed the success story indicated by the greater agronomic characters and yield compared to the elder and also another check variety. In addition, the presence of multi-locations test in our sorghum mutant strains were aimed to achieve some benefits such as to determine the range of actual yield, to select the best line, and to determine its cultivation recommendations.

In conclusion, the mutation treatment through gamma irradiation method combined with in vitro culture in sweet sorghum variety, namely Numbu produced a new diversity of mutant strain that showed different responses in eight study sites. There was genetic $\mathrm{x}$ environment interaction that significantly affected the agronomic characters and yield components of tested sweet sorghum. Sweet sorghum mutants that were genetically modified showed greater agronomic characters and yield compared to Numbu as an elder or Super 1 as another check variety. The highest seed yield was found in MB-1 strain of sweet sorghum mutant that cultivated in Pekalongan site, i.e 9.26 t/ha.

\section{ACKNOWLEDGEMENTS}

This work was supported by the KP4S program number 55.31/hm.23/h.1/03/2017 and BB BIOGEN DIPA in 2017. We thank the head of Indonesian Cereals Research Institute, the head of BPTP of West Nusa Tenggara, the head of BPTP of Lampung, the head of agriculture office of Pekalongan, the head of experimental garden in Maros, Kendalpayak-Malang, and Bontobili for helping the implementation of this work.

\section{REFERENCES}

Alghamdi SS. 2004. Yield stability of some soybean genotypes across diverse environments. Pakistan J Biol Sci 7 (12): 2109-2114.

Almodares A, Hadi MR, Ranjbar M, Taheri R. 2007. The effect of nitrogen treatment, cultivars and harvest stages on stalk, yield and sugar content in sweet sorghum. Asian J Plant Sci 6: 423-426.

Almodares A, Hadi M. 2009. Production of bioethanol from sweet sorghum: A review. J Agric Res 4: 772-780.

Anasari NR, Kendarini N, Purnamaningsih SL. 2017. Interaksi genotipx lingkungan pada empat genotip pakchoy (Brassica rapa L.) di tiga lokasi. J Produksi Tanaman 5 (1): 54-60. [Indonesian]

Carvallho CGP, Arias CAA, Almeida LA, de Toledo JFF, Oleivera, M F. (2002). Genotype and environment interaction on soybean yield in Parana state, Brazil. Pesq Agropec Bras 37: 785-792.

Cheema, Khalsa SK. 2018. Plant breeding its applications and future prospects. Intl J Eng Tech Sci Res 5: 88-94.

DeLacy IH, Kaul S, Rana BS, Cooper M. 2010. Genotypic variation for grain and stover yield of dryland (rabi) sorghum in India: characterization of genotype $\times$ environment interactions. Field Crops Res 118: 236-242.

Htun KW, Win NC, Minn M. 2015. The improvement of sorghum (Sorghum bicolor L.) for high yield through induced mutation. Proceedings of $5^{\text {th }}$ ISERD International Conference 1: 95-98.

Human S, Sihono. 2010. Sorghum breeding for improved drought tolerance using induced mutation with gamma irradiation. J Agron Indon 38: 95-99.

Jain SM. 2006. Mutation-assisted breeding for improving ornamental plants. Acta Hortic 714: 85-98.

Jain SM. 2010. Mutagenesis in crop improvement under climate change. Romanian Biotechnological Lett 15: 88-106.

Kharkwal, M. C, Pandey, R. N, and Pawar, S. E. (2004). Mutation breeding for crop improvement. In: Jain HK, Kharkwal MC. (eds) Plant Breeding. Springer, Dordrecht.

Kumar N, Reddy MP. 2014. In vitro plant propagation: A review. J For Sci 27: 61-72.

Lestari EG, Dewi IS, Yunita R, Sukmadjaja D. 2017. Induksi mutasi dan keragaman somaklonal untuk meningkatkan ketahanan penyakit blas daun pada padi Fatmawati. Buletin Plasma Nutfah 16: 96-102. [Indonesian]

Mudibu J, Nkongolo KKC, Kalonji-Mbuyi A, Kizungu RV. 2012. Effect of gamma irradiation on morpho-agronomic characteristics of soybeans (Glycine max L.). Am J Plant Sci 3: 331-337.

Mut Z, Aydin N, Bayramoglu HO, Ozcan H. 2010. Stability of some quality traits in bread wheat (Triticum aestivum) genotypes. J Environ Biol 31: 489-495.

Oladosu YY, Rafii MY, Abdullah N, Hussin G, Ramlia, Rahim BVG, Miah, Usman M. 2016. Principle and application of plant mutagenesis in crop improvement: A review. Biotechnol Biotechnol Equipt 30: 116.

Pabendon MB, Efendi R, Santoso S, Prastowo B. 2017. Varieties of sweet sorghum Super-1 and Super-2 and its equipment for bioethanol in Indonesia. IOP Conference Series: Earth Environ Sci 65: 1-10

Pabendon MB, Sarungallo R, Mas'ud S. 2012. Pemanfaatan nira batang, bagas, dan biji sorgum manis sebagai bahan baku bioetanol. Penelitian Pertanian Tanaman Pangan 31: 180-187. [Indonesian]

Pedriery S. 2001. Mutation induction and tissue culture in improving fruits. Plant Cell Tissue Organ Cult 64: 185-210.

Rahayu S, Dewi AK, Wirnas D. 2013. Analisis Stabilitas dan adaptabilitas beberapa galur padi dataran tinggi hasil mutasi induksi. J Ilmiah Aplikasi Isotop Radiasi 9: 81-90. [Indonesian]

Rayad, Idwar. 2010. Interaksi genetik x lingkungan dan stabilitas komponen hasil berbagai genotipe kedelai di Provinsi Riau. Indones J Agron 38: 25-29. [Indonesian]

Regassa TH, Wortmann CS. 2014. Sweet sorghum as a bioenergy crop: literature review. Biomass Bioenergy 64: 348-355.

Roychowdhury, R, Tah, J. 2011a. Assessment of chemical mutagenic effects in mutation breeding programme for M1 generation of Carnation (Dianthus caryophyllus). Res Plant Biol 1 (4): 23-32.

Roychowdhury R, Tah J. 2011b. Research Note Mutation breeding in Dianthus caryophyllus for economic traits. Elec J Plant Breed 2 (2): 282-286.

Sungkono, Trikoesoemaningtyas, Wirnas D, Sopandie D, Human S, Yudiarto MA. 2009. Estimation of genetic parameters and selection of sorghum mutant lines under acid soil stress conditions. Indon J Agron 37: 220-225.

Wanga MA, Kumar AA, Kangueehi GN, Shimelis H, Horn LN, Sarsu FJ, Andowa FN. 2018. Breeding sorghum using induced mutations: Future prospect for Namibia. Am J Plant Sci 9: 2696-2707.

Yuliasti. 2016. Genotype x environment interaction and stability analysis of promising mutant lines of mungbean (Vigna radiata (L.)). J Ilmiah Aplikasi Isotop Radiasi 12: 37-48. [Indonesian]

Yuliasti Y, Reflinur R. 2017. Field performance of five soybean mutants under drought stress conditions and molecular analysis using SSR markers. Atom Indonesia 43: 103-109. 